\title{
Radiation Ionizing Radiotherapy
}

National Cancer Institute

\section{Source}

National Cancer Institute. Radiation lonizing Radiotherapy. NCI Thesaurus. Code C15846.

The use of ionizing radiation to kill cancer cells 